\title{
New Topics in Vasopressin Receptors and Approach to Novel Drugs: Role of the Vasopressin Receptor in Psychological and Cognitive Functions
}

\author{
Nobuaki Egashira ${ }^{1,2, *}$, Kenichi Mishima ${ }^{1}$, Katsunori Iwasaki ${ }^{1}$, Ryozo Oishi $^{2}$, and Michihiro Fujiwara ${ }^{1}$ \\ ${ }^{\prime}$ Department of Neuropharmacology, Faculty of Pharmaceutical Sciences, Fukuoka University, Fukuoka 814-0180, Japan \\ ${ }^{2}$ Department of Pharmacy, Kyushu University Hospital, Fukuoka 812-8582, Japan
}

Received September 25, 2008; Accepted November 6, 2008

\begin{abstract}
Arginine vasopressin (AVP) is a neurohypophyseal peptide best known as an antidiuretic hormone. AVP receptors have been classified into three subtypes: V1a, V1b, and V2 receptors. V1a receptor $(\mathrm{V} 1 \mathrm{aR})$ and $\mathrm{V} 1 \mathrm{~b}$ receptor $(\mathrm{V} 1 \mathrm{bR})$ are widely distributed in the central nervous system, including the septum, cortex, hippocampus, and hypothalamus. Clinical studies have demonstrated an involvement of AVP in psychiatric disorders. In the present study, we examined the performance of V1aR or V1bR knockout (KO) mice compared to wild-type (WT) mice in behavioral tests. V1aR and V1bR KO mice exhibited deficits of social behavior and prepulse inhibition in comparison to WT mice. Moreover, V1aR KO mice exhibited reduced anxiety-like behavior and impairment of spatial learning. These results suggest that V1aR and V1bR play an important role in psychological and cognitive functions.
\end{abstract}

Keywords: arginine vasopressin, V1a receptor, V1b receptor, behavior, psychiatric disorder, knockout mice

\section{Introduction}

Arginine vasopressin (AVP) is a neurohypophyseal peptide. AVP receptors have been classified into three subtypes: V1a, V1b, and $\mathrm{V} 2$ receptors $(1,2)$, based on their intracellular transduction mechanisms. The V1a and $\mathrm{V} 1 \mathrm{~b}$ receptors are associated with phosphoinositol turnover, while the V2 receptor activates adenylate cyclase $(3,4)$. We previously reported that AVP-(4-9) and its analog improved the scopolamine-induced impairment of spatial memory in an eight-arm radial maze, and these ameliorative effects were suppressed by a V1a receptor (V1aR) antagonist but not by a V2 receptor (V2R) antagonist $(5-7)$. The V1aR is widely distributed in the central nervous system including the septum, cerebral cortex, hippocampus, and hypothalamus $(8-10)$, suggesting a potential role in learning and memory. The $\mathrm{V} 1 \mathrm{~b}$ receptor $(\mathrm{V} 1 \mathrm{bR})$ also is widely

*Corresponding author (affiliation \#2).

n-egashi@pharm.med.kyushu-u.ac.jp

Published online in J-STAGE

doi: 10.1254/jphs.08R14FM distributed in the central nervous system including the cerebral cortex, hippocampus, and hypothalamus (11, 12). A recent study showed that the hypothalamicpituitary-adrenal (HPA) axis activity is suppressed in V1bR knockout $(\mathrm{KO})$ mice under both stress and resting conditions (13). V1bR KO mice have also been reported to exhibit markedly reduced aggressive behavior (14). Moreover, it has been reported that a selective V1bR antagonist produced anxiolytic- and antidepressant-like effects in rodents $(15,16)$ and reversed stress-induced suppression of neurogenesis in a mouse model of depression (17). These findings suggest that V1bR regulates the HPA system and plays a potential role in stress-related behavior. On the other hand, V2R is mainly distributed in the kidney and is involved in the antidiuretic action of AVP.

The present article introduces our recent study related to the role of AVP receptor in psychological and cognitive functions.

\section{AVP and psychiatric disorder}

Depression: Clinical studies have demonstrated an 
involvement of AVP in psychiatric disorders. In depressed patients, plasma levels of AVP $(18,19)$, the number of AVP-expressing cells, or the levels of AVP in the paraventricular nucleus $(20,21)$ and the response of pituitary AVP are increased (22). The AVP mRNA in the supraoptic nucleus is also enhanced in depressed subjects (23). Interestingly, plasma AVP levels are positively correlated with cortisol levels in depression, particularly in suicide victims $(24-26)$. Furthermore, a single nucleotide polymorphism (SNP) of the V1bR has been found to protect against major depression (27).

Anxiety: Several anxiety disorders are also associated with elevated AVP. For example, elevated plasmatic levels of AVP have been reported in PTSD patients (28). The AVP concentrations in both the cerebrospinal fluid and the plasma of patients with obsessive-compulsive disorder (OCD) are elevated (29). In panic patients, infusion of sodium lactate or hypertonic saline produces panic symptoms, associated with an increase of plasmatic AVP; these alterations are not found in the controls subjects (30), suggesting an involvement of AVP in the pathophysiology of panic induction.

Schizophrenia: It has been shown that schizophrenic patients display selective impairments in response to psychosocial stress but not physical stress (31). These findings suggest that HPA stress responses may be abnormal in schizophrenic patients. The HPA stress response is dependent on the type of stressor that is used (32). The physical stimuli activate the HPA-axis responses mostly via corticotropin-releasing hormone $(\mathrm{CRH})$, and the psychological stimuli mostly via AVP. It has also been reported that baseline plasma AVP levels were lower in schizophrenic patients and progressively increased following acute metabolic stress like 2-deoxyD-glucose (2DG) (33). On the other hand, heightened plasma AVP levels are associated with acute schizophrenia (34). In addition, neonatal lesions of the ventral hippocampal formation, which replicates several features of schizophrenia, disrupt neuroendocrine (including AVP) responses to auditory stress in adult rats (35). Thus, AVP may be implicated in the course of schizophrenia.

Autism: AVP plays an important role in social behavior in comparative neurobiological studies (36). Most recently, intranasally-delivered AVP has been reported to affect social communication processes in humans (37). One of the core features of autism is impairment in social behavior such as reciprocal social interaction and communication. Interestingly, three independent reports demonstrated that autism has been associated with the V1aR gene $(38-40)$. On the other hand, impairments of social function are often observed in symptoms of schizophrenia. Phencyclidine (PCP) has been known to evoke increased severity of symptoms in schizophrenia and to induce schizophrenia-like symptoms in healthy individuals $(41,42)$. Moreover, PCP decreases social behavior in the rat social interaction test (43). Similarly, subchronic treatment with PCP results in impaired social interaction and reduced density of $\mathrm{V} 1 \mathrm{aR}$ in several brain regions such as the hypothalamus in rats (44). Moreover, NC-1900, an AVP analogue, ameliorates social behavior deficits induced by MK-801, an $N$-methyl-D-aspartate (NMDA)-receptor antagonist (45). There is a possibility that $\mathrm{V} 1 \mathrm{aR}$ may play an important role in the regulation of social interaction. This idea is of special interest because impaired social interaction is among the core deficits of autistic disorders.

\section{Characteristics of psychological and cognitive behav- ior in V1aR and V1bR KO mice}

To investigate the role of AVP receptor in psychological and cognitive functions, we examined the behavior related to learning, sociality, information processing, and affectivity in mice lacking the $\mathrm{VlaR}$ or V1bR compared to wild-type (WT) mice. Here, we report on the characteristics of behavior in these mice (Table 1).

First, we found that $\mathrm{V} 1 \mathrm{aR}$ and $\mathrm{V} 1 \mathrm{bR} \mathrm{KO}$ mice exhibited an impairment of social interaction compared

Table 1. Characteristics of psychological and cognitive behavior in V1aR and V1bR KO mice

\begin{tabular}{lcc}
\hline Measurement & V1aR KO & V1bR KO \\
\hline Motor function & - & - \\
Open-field test & - & - \\
Traction meter test & - & - \\
Rota-rod test & & - \\
Anxiety & $\downarrow$ & - \\
Plus maze test & $\downarrow$ & - \\
Marble-burying test & & - \\
Depression & - & - \\
Forced swimming test & & $\downarrow$ \\
Learning and Memory & $\downarrow$ & $\uparrow$ \\
Water maze test & & $\downarrow$ \\
8-Arm radial maze test & $\downarrow$ & \\
Sensorimotor gating & $\uparrow$ & \\
Prepulse inhibition & & \\
Startle response & $\downarrow$ & \\
Social behavior & & \\
Social interaction test & & \\
\hline
\end{tabular}

$\downarrow$ : impairment or decrease, $\uparrow:$ increase, —: non-effect. 
to the WT mice in the social interaction test. The results of the study also showed that the number of ambulation and rearing in the V1aR and V1bR KO mice was normal in the open-field test. Moreover, we did not observe differences among V1aR KO, V1bR KO, and WT mice in the traction-meter (for muscle tone) and rota-rod (for motor coordination) tests. Thus, motor function in $\mathrm{V} 1 \mathrm{aR}$ and V1bR KO mice was normal. Moreover, there was no significant difference among V1aR KO, V1bR KO, and WT mice for the immobility time in the forced swimming test for measuring depression. In addition, these different types of mice showed no difference in body weight. We also observed that $\mathrm{V} 1 \mathrm{aR} \mathrm{KO}$ mice showed reduced anxiety-related behavior (46), whilst V1bR KO mice showed normal anxiety levels in the elevated plus-maze test. Therefore, it is unlikely that social interaction is impaired in V1aR and V1bR KO mice because of a deficit in motor function, depression, and high anxiety. These findings suggest that V1aR and V1bR controls social interaction in particular. This idea is supported by the findings that subchronic treatment with PCP, an animal model of schizophrenia, results in impaired social interaction and reduced density of V1aR in several brain regions (44). Moreover, the V1aR gene has been linked to autism, providing evidence that the V1aR gene may play a role in social communication and behavior in humans $(38-40)$. In addition, V1bR $\mathrm{KO}$ mice have been reported to exhibit reduced social motivation in the olfactory discrimination task (47).

Second, the V1aR KO mice showed reduced anxietyrelated behavior, whilst V1bR KO mice showed normal anxiety levels in the elevated plus-maze test. On the other hand, these mice performed normally in the forced swimming test. The present findings are consistent with previous findings $(14,48)$. The increased AVP expression in the hypothalamic paraventricular nucleus is considered to underlie anxiety-related behavior (49). Also, the microinjection of V1-receptor antagonist into the septal nucleus of rats has been reported to reduce the anxiety in the elevated plus-maze test (50). Furthermore, overexpression of the V1aR in the lateral septum of WT mice resulted in an increase in anxiety-related behavior (51). Therefore, V1aR may be involved in the anxietyrelated behavior.

Third, the V1aR KO mice buried significantly fewer glass marbles than the WT mice did in the marbleburying behavior test (46). On the other hand, there was no significant difference between V1bR KO mice and WT mice in the number of buried glass marbles. This phenomenon does not seem to contribute to a change in locomotor activity, since there were no genotypic differences in locomotor activity during the marbleburying behavior. It has been suggested that the burying behavior would be rewarding or compulsive (52). In general, the marble-burying behavior test has been considered as an animal model of OCD (53). Therefore, the reduced number of marbles buried by V1aR KO mice might reflect an anti-OCD effect of the mutation. Alternatively, the interpretation that mice have anxiety when they are burying foreign objects is based on the assumption that the animals would consider marbles startling by virtue of their novelty. Therefore, the reduced number of marbles buried by $\mathrm{VlaR} \mathrm{KO}$ mice might reflect an anxiolytic effect of the mutation. This idea is supported by the present finding that the VlaR $\mathrm{KO}$ mice showed reduced anxiety-related behavior in the elevated plus-maze test.

Fourth, we found that VlaR KO mice exhibit an impairment of spatial learning in comparison to WT mice in an eight-arm radial maze (54). By contrast, we did not observe any significant differences between the V1bR KO mice and the WT mice in the eight-arm radial maze. We also examined the performance of V1aR KO mice compared to WT mice in a Morris water maze. This task is a simple orientation toward a fixed hidden platform from a single start position. However, $\mathrm{VlaR} \mathrm{KO}$ mice did not exhibit an impairment of spatial memory in the Morris water maze. Thus, V1aR KO mice exhibited the impairment of performance in the eight-arm radial maze requiring working memory or the higher level of spatial memory. V1aR may control spatial memory, especially working memory or higher level of spatial memory in mice. On the other hand, V1bR KO mice have been reported to exhibit markedly reduced aggressive behavior and normal spatial memory performance in the Morris water maze (14). Moreover, we found that V1bR KO mice displayed normal spatial memory performance in the eight-arm radial maze. These findings suggest that V1bR plays a potential role in an emotional response such as aggression but not spatial memory.

Fifth, we found that $\mathrm{V} 1 \mathrm{aR}$ and $\mathrm{V} 1 \mathrm{bR} \mathrm{KO}$ mice displayed significantly reduced levels of prepulse inhibition (PPI) of the startle reflex, reminiscent of the sensorimotor gating deficits observed in a large majority of schizophrenic patients. In addition to PPI deficits, V1aR and V1bR KO mice showed an increased acoustic startle response. However, the acoustic startle response was not significantly correlated to the PPI of the startle reflex in V1aR and V1bR KO mice. The results of the present study indicate that V1aR and V1bR may be involved in regulating PPI of the startle reflex. Interestingly, Brattleboro rats, in which the ability to synthesize AVP is impaired, have been reported to exhibit deficits of PPI of the startle reflex and a high startle response $(55,56)$. Moreover, individual startle responses and PPI 
in these rats were not correlated like in our current results. Therefore, V1aR and V1bR might be involved in the PPI deficits in Brattleboro rats.

Moreover, PPI deficits observed in the V1bR KO mice are significantly reversed by atypical antipsychotics such as risperidone and clozapine but not by the typical neuroleptic haloperidol (57). Our results are in good agreement with clinical data obtained from schizophrenic patients. Indeed, deficits in the sensorimotor gating processes are commonly shown in schizophrenic patients using PPI of the startle reflex $(58,59)$. These PPI deficits seem to be best treated by atypical antipsychotics, as risperidone and clozapine normalized information processing functions in schizophrenic patients whereas this was not the case in such patients treated with typical neuroleptics (60). Also, to normalize PPI deficits, atypical antipsychotics such as risperidone and clozapine probably interact with the brain systems of V1bR KO mice. Interestingly, the PPI deficits observed in Brattleboro rats were also reversed by acute administration of clozapine but not by acute administration of haloperidol (56). These findings suggest that these deficits might be particularly sensitive to some critical properties of those antipsychotic drugs. Significantly, the PPI deficits in V1bR KO mice were not reversed by haloperidol, a dopamine $\mathrm{D}_{2}$-receptor antagonist. Haloperidol's lack of efficacy indicates that excessive dopamine transmission is not likely to fully account for the PPI deficits seen in V1bR KO mice. On the other hand, risperidone and clozapine are potent not only as dopamine $\mathrm{D}_{2}$-receptor antagonists, but also have serotonin $5-\mathrm{HT}_{2 \mathrm{~A}}-$ receptor antagonist properties. The PPIdisruptive effects of DOI, a 5-HT $\mathrm{H}_{2 \mathrm{~A}}$-receptor agonist, are reversed by risperidone and clozapine but not by haloperidol (61). Also, a 5- $\mathrm{HT}_{2}-$ receptor antagonist ketanserin has been reported to reverse the PPI deficits induced by an NMDA antagonist (62). However, we failed to find that ketanserin reversed the PPI deficits in V1bR KO mice in this study. Therefore, it is possible that risperidone and clozapine reverse PPI deficits in V1bR KO mice through a concurrent blockade of dopamine $\mathrm{D}_{2}$ and serotonin $5-\mathrm{HT}_{2 \mathrm{~A}}$ receptors. More importantly, we found that V1bR KO mice showed a decrease in basal levels of extracellular dopamine in the medial prefrontal cortex compared to WT mice, while extracellular serotonin in the same site showed no difference between the two genotypes. Therefore, V1bR may regulate dopamine release in the medial prefrontal cortex. The medial prefrontal cortex is thought to be an important brain region within the neuronal circuit response for PPI (63). Also, dopaminergic hypofunction in the prefrontal cortex is related to the etiology of negative symptoms of schizophrenia (64). Furthermore,
PPI is reduced by manipulations of dopaminergic hypofunction in the medial prefrontal cortex by infusion of 6-hydroxydopamine (6-OHDA) (65) or dopamine $\mathrm{D}_{1}$ or $\mathrm{D}_{2}$ antagonists (66). These findings suggest that dopaminergic hypofunction in the medial prefrontal cortex may be involved in PPI deficits in V1bR KO mice. Hence, risperidone and clozapine may be able to increase dopamine release in the medial prefrontal cortex. Apparently consistent with this possibility, a recent study proposed that risperidone and clozapine could increase dopamine release in the medial prefrontal cortex (67-69). Moreover, these effects of atypical antipsychotics are exerted through blockade of $\mathrm{D}_{2}$ and $5-\mathrm{HT}_{2 \mathrm{~A}}$ receptors (69). On the other hand, haloperidol has been reported to increase dopamine release in the nucleus accumbens but not in the medial prefrontal cortex (68). Given these findings, the medial prefrontal cortex may be a critical site for the deficit of PPI of the startle reflex in V1bR KO mice, and risperidone and clozapine may improve these deficits via an increase in dopamine release at this site.

\section{Conclusions}

In conclusion, the present report shows that $\mathrm{V} 1 \mathrm{aR}$ and V1bR may be involved in the regulation of social interaction and PPI of the startle reflex. Moreover, the results of the present experiments indicate that V1aR controls anxiety-related behavior and spatial memory. Hence, the V1aR- or V1bR-related drugs have become the focus of intense interest as the first in this novel class of drugs for the treatment of psychiatric disorders and memory disturbance.

\section{Acknowledgments}

This study was supported in part by a Grant-in-Aid for Scientific Research from the Ministry of Education, Culture, Sports, Science, and Technology of Japan (No. 18591318).

\section{References}

1 Jard S, Barberis C, Audigier S, Tribollet E. Neurohypophyseal hormone receptor systems in brain and periphery. Prog Brain Res. 1987;72:173-187.

2 Thibonnier M, Coles P, Thibonnier A, Shoham M. Molecular pharmacology and modeling of vasopressin receptors. Prog Brain Res. 2002;139:179-196.

3 Gouzenes L, Sabatier N, Richard P, Moos FC, Dayanithi G. V1aand V2-type vasopressin receptors mediate vasopressin-induced $\mathrm{Ca}^{2+}$ responses in isolated rat supraoptic neurons. J Physiol. 1999;517:771-779.

4 Omura T, Nabekura J, Akaike N. Intracellular pathways of V1 and V2 receptors activated by arginine vasopressin in rat hippocampal neurons. J Biol Chem. 1999;274:32762-32770. 
5 Fujiwara M, Ohgami Y, Inada K, Iwasaki K. Effect of active fragments of arginine-vasopressin on the disturbance of spatial cognition in rats. Behav Brain Res. 1997;83:91-96.

6 Mishima K, Tsukikawa H, Inada K, Fujii M, Iwasaki K, Matsumoto $Y$, et al. Ameliorative effect of vasopressin-(4-9) through vasopressin V1A receptor on scopolamine-induced impairments of rat spatial memory in the eight-arm radial maze. Eur J Pharmacol. 2001;427:43-52.

7 Mishima K, Tsukikawa H, Miura I, Inada K, Abe K, Matsumoto Y, et al. Ameliorative effect of NC-1900, a new AVP4-9 analog, through vasopressin V1A receptor on scopolamine-induced impairments of spatial memory in the 8-arm radial maze. Neuropharmacology. 2003;44:541-552.

8 Hirasawa A, Hashimoto K, Tsujimoto G. Distribution and development change of vasopressin V1A and V2 receptor mRNA in rats. Eur J Pharmacol. 1994;267:71-75.

9 Szot P, Bale TL, Dorsa DM. Distribution of messenger RNA for the vasopressin V1a receptor in the CNS of male and female rats. Brain Res Mol Brain Res. 1994;24:1-10.

10 Tribollet E, Raufaste D, Maffrand JP, Serradeli-Le Gal C. Binding of the non-peptide vasopressin V1a receptor antagonist SR-49059 in the rat brain: an in vitro and in vivo autoradiographic study. Neuroendocrinology. 1999;69:113-120.

11 Lolait SJ, O'Carroll AM, Mahan LC, Felder CC, Button DC, Young WS III, et al. Extrapituitary expression of the rat V1b vasopressin receptor gene. Proc Natl Acad Sci U S A. 1995;92: 6783-6787.

12 Vaccari C, Lolait SJ, Ostrowski NL. Comparative distribution of vasopressin $\mathrm{V} 1 \mathrm{~b}$ and oxytocin receptor messenger ribonucleic acids in brain. Endocrinology. 1998;139:5015-5033.

13 Tanoue A, Ito S, Honda K, Oshikawa S, Kitagawa Y, Koshimizu $\mathrm{T}$, et al. The Vasopressin $\mathrm{V} 1 \mathrm{~b}$ receptor critically regulates hypothalamic-pituitary-adrenal axis activity under both stress and resting conditions. J Clin Invest. 2004;113:302-309.

14 Wersinger SR, Ginns EI, O'Carroll A-M, Lolait SJ, Young III WS. Vasopressin V1b receptor knockout reduces aggressive behavior in male mice. Mol Psychiatry. 2002;7:975-984.

15 Griebel G, Simiand J, Serradeil-Le Gal C, Wagnon J, Pascal M, Scatton B, et al. Anxiolytic- and antidepressant-like effects of the non-peptide vasopressin V1b receptor antagonist, SSR149415, suggest an innovative approach for the treatment of stress-related disorders. Proc Natl Acad Sci U S A. 2002;99: 6370-6375.

16 Serradeil-Le Gal C, Wagnon J, Simiand J, Griebel G, Lacour C, Guillon G, et al. Characterization of (2S,4R)-1-[5-chloro-1-[(2,4dimethoxyphenyl)sulfonyl]-3-(2-methoxy-phenyl)-2-oxo-2,3-dihydro-1H-indol-3-yl]-4-hydroxy-N,N-dimethyl-2-pyrrolidine carboxamide (SSR149415), a selective and orally active vasopressin V1b receptor antagonist. J Pharmacol Exp Ther. 2002;300:1122-1130.

17 Alonso R, Griebel G, Pavone G, Stemmelin J, Le Fur G, Soubrie P. Blockade of CRF1 or V1b receptors reverses stress-induced suppression of neurogenesis in a mouse model of depression. Mol Psychiatry. 2004;9:278-286.

18 van Londen L, Goekoop JG, van Kempen GM, FrankhuijzenSierevogel AC, Wiegant VM, van der Velde EA, et al. Plasma levels of arginine vasopressin elevated in patients with major depression. Neuropsychopharmacology. 1997;17:284-292.

19 van Londen L, Kerkhof GA, van den Berg F, Goekoop JG, Zwinderman KH, Frankhuijzen-Sierevogel AC, et al. Plasma arginine vasopressin and motor activity in major depression. Biol Psychiatry. 1998;43:196-204.
20 Merali Z, Kent P, Du L, Hrdina P, Palkovits M, Faludi G, et al. Corticotropin-releasing hormone, arginine vasopressin, gastrinreleasing peptide, and neuromedin B alterations in stressrelevant brain regions of suicides and control subjects. Biol Psychiatry. 2006;59:594-602.

21 Purba JS, Hoogendijk WJ, Hofman MA, Swaab DF. Increased number of vasopressin- and oxytocin-expressing neurons in the paraventricular nucleus of the hypothalamus in depression. Arch Gen Psychiatry. 1996;53:137-143.

22 Dinan TG, Lavelle E, Scott LV, Newell-Price J, Medbak S, Grossman AB. Desmopressin normalizes the blunted adrenocorticotropin response to corticotropin-releasing hormone in melancholic depression: evidence of enhanced vasopressinergic responsivity. J Clin Endocrinol Metab. 1999;84:2238-2240.

23 Meynen G, Unmehopa UA, van Heerikhuize JJ, Hofman MA, Swaab DF, Hoogendijk WJ. Increased arginine vasopressin mRNA expression in the human hypothalamus in depression: A preliminary report. Biol Psychiatry. 2006;60:892-895.

24 Brunner J, Keck ME, Landgraf R, Uhr M, Namendorf C, Bronisch T. Vasopressin in CSF and plasma in depressed suicide attempters: preliminary results. Eur Neuropsychopharmacol. 2002;12:489-494.

25 Inder WJ, Donald RA, Prickett TC, Frampton CM, Sullivan PF, Mulder RT, et al. Arginine vasopressin is associated with hypercortisolemia and suicide attempts in depression. Biol Psychiatry. 1997;42:744-747.

26 de Winter RF, van Hemert AM, DeRijk RH, Zwinderman KH, Frankhuijzen-Sierevogel AC, Wiegant VM, et al. Anxiousretarded depression: relation with plasma vasopressin and cortisol. Neuropsychopharmacology. 2003;28:140-147.

27 van West D, Del-Favero J, Aulchenko Y, Oswald P, Souery D, Forsgren $\mathrm{T}$, et al. A major SNP haplotype of the arginine vasopressin 1B receptor protects against recurrent major depression. Mol Psychiatry. 2004;9:287-292.

28 de Kloet CS, Vermetten E, Geuze E, Wiegant VM, Westenberg HG. Elevated plasma arginine vasopressin levels in veterans with posttraumatic stress disorder. J Psychiatr Res. 2008;42:192-198.

29 Altemus M, Cizza G, Gold PW. Chronic fluoxetine treatment reduces hypothalamic vasopressin secretion in vitro. Brain Res. 1992;593:311-313.

30 Peskind ER, Jensen CF, Pascualy M, Tsuang D, Cowley D, Martin DC, et al. Sodium lactate and hypertonic sodium chloride induce equivalent panic incidence, panic symptoms, and hypernatremia in panic disorder. Biol Psychiatry. 1998;44:1007-1016.

31 Jansen LM, Gispen-de Wied CC, Kahn RS. Selective impairments in the stress response in schizophrenic patients. Psychopharmacology. 2000;149:319-325.

32 Romero LM, Sapolsky RM. Patterns of ACTH secretagog secretion in response to psychological stimuli. J Neuroendocrinol. 1996;8:243-258.

33 Elman I, Lukas S, Shoaf SE, Rott D, Adler C, Breier A. Effects of acute metabolic stress on the peripheral vasopressinergic system in schizophrenia. J Psychopharmacol. 2003;17:317-323.

34 Raskind MA, Courtney N, Murburg MM, Backus FI, Bokan JA, Ries RK, et al. Antipsychotic drugs and plasma vasopressin in normals and acute schizophrenic patients. Biol Psychiatry. 1987;22:453-462.

35 Mitchell CP, Goldman MB. Neonatal lesions of the ventral hippocampal formation disrupt neuroendocrine responses to auditory stress in the adult rat. Psychoneuroendocrinology. 2004;29:1317-1325.

36 Insel TR, Young LJ. Neuropeptides and the evolution of social 
behavior. Curr Opin Neurobiol. 2000;10:784-789.

37 Thompson RR, George K, Walton JC, Orr SP, Benson J. Sexspecific influences of vasopressin on human social communication. Proc Natl Acad Sci U S A. 2006;103:7889-7894.

38 Kim S-J, Young LJ, Gonen D, Veenstra-VanderWeele J, Courchesne R, Courchesne E, et al. Transmission disequilibrium testing of arginine vasopressin receptor 1A (AVPR1A) polymorphisms in autism. Mol Psychiatry. 2002;7:503-507.

39 Wassink TH, Piven J, Vieland VJ, Pietila J, Goedken RJ, Folstein SE, et al. Examination of AVPR1a as an autism susceptibility gene. Mol Psychiatry. 2004;9:968-972.

40 Yirmiya N, Rosenberg C, Levi S, Salomon S, Shulman C, Nemanov L, et al. Association between the arginine vasopressin 1a receptor (AVPRla) gene and autism in a family-based study: mediation by socialization skills. Mol Psychiatry. 2006;11:488494.

41 Murray JB. Phencyclidine (PCP): a dangenous drug, but useful in schizophrenia research. J Psychol. 2002;136:319-327.

42 Tsai G, Coyle JT. Glutamatergic mechanisms in schizophrenia. Annu Rev Pharmacol Toxicol. 2002;42:165-179.

43 Sams-Dodd F. Phencyclidine in the social interaction test: an animal model of schizophrenia with face and predictive validity. Rev Neurosci. 1999;10:59-90.

44 Tanaka K, Suzuki M, Sumiyoshi T, Murata M, Tsunoda M, Kurachi M. Subchronic phencyclidine administration alters central vasopressin receptor binding and social interaction in the rat. Brain Res. 2003;992:239-245.

45 Matsuoka T, Sumiyoshi T, Tanaka K, Tsunoda M, Uehara T, Itoh $\mathrm{H}$, et al. NC-1900, an arginine-vasopressin analogue, ameliorates social behavior deficits and hyperlocomotion in MK-801-treated rats: therapeutic implications for schizophrenia. Brain Res. 2005; 1053:131-136.

46 Egashira N, Tanoue A, Matsuda T, Koushi E, Harada S, Takano $\mathrm{Y}$, et al. Impaired social interaction and reduced anxiety-related behavior in vasopressin V1a receptor knockout mice. Behav Brain Res. 2007;178:123-127.

47 Wersinger SR, Kelliher KR, Zufall F, Lolait SJ, O'Carroll AM, Young WS III. Social motivation is reduced in vasopressin $1 \mathrm{~b}$ receptor null mice despite normal performance in an olfactory discrimination task. Horm Behav. 2004;46:638-645.

48 Bielsky IF, Hu S-B, Szegda KL, Westphal H, Young LJ. Profound impairment in social recognition and reduction in anxiety-like behavior in vasopressin V1a receptor knockout mice. Neuropsychopharmacology. 2004;29:483-493.

49 Landgraf R. The involvement of the vasopressin system in stress-related disorders. CNS Neurol Disord Drug Targets. 2006;5:167-179.

50 Liebsch G, Wotjak CT, Landgraf R, Engelmann M. Septal vasopressin modulates anxiety-related behaviour in rats. Neurosci Lett. 1996;217:101-104.

51 Bielsky IF, Hu S-B, Ren X, Terwilliger EF, Young LJ. The V1a vasopressin receptor is necessary and sufficient for normal social recognition: a gene replacement study. Neuron. 2005;47:503513.

52 Broekkamp CL, Rijk HW, Joly-Gelouin D, Lloyd KL. Major tranquillizers can be distinguished from minor tranquillizers on the basis of effects on marble burying and swim-induced grooming in mice. Eur J Pharmacol. 1986;126:223-229.

53 Matsushita M, Egashira N, Harada S, Okuno R, Mishima K, Iwasaki $\mathrm{K}$, et al. Perospirone, a novel antipsychotic drugs, inhibits marble-burying behavior via $5-\mathrm{HT}_{1 \mathrm{~A}}$ receptor in mice: implications for obsessive-compulsive disorder. J Pharmacol
Sci. 2005;99:154-159.

54 Egashira N, Tanoue A, Higashihara F, Mishima K, Fukue Y, Takano Y, et al. V1a receptor knockout mice exhibit impairment of spatial memory in an eight-arm radial maze. Neurosci Lett. 2004;356:195-198.

55 Feifel D, Priebe K. Vasopressin-deficient rats exhibit sensorimotor gating deficits that are reversed by subchronic haloperidol. Biol Psychiatry. 2001;50:425-433.

56 Feifel D, Melendez G, Shilling PD. Reversal of sensorimotor gating deficits in Brattleboro rats by acute administration of clozapine and a neurotensin agonist, but not haloperidol: a potential predictive model for novel antipsychotic effects. Neuropsychopharmacology. 2004;29:731-738.

57 Egashira N, Tanoue A, Higashihara F, Fuchigami H, Sano K, Mishima K, et al. Disruption of the prepulse inhibition of the startle reflex in vasopressin $\mathrm{V} 1 \mathrm{~b}$ receptor knockout mice: reversal by antipsychotic drugs. Neuropsychopharmacology. 2005;30:1996-2005.

58 Braff DL, Grillon C, Geyer MA. Gating and habituation of the startle reflex in schizophrenic patients. Arch Gen Psychiatry. 1992;49:206-215.

59 Parwani A, Duncan EJ, Bartlett E, Madonick SH, Efferen TR, Rajan R, et al. Impaired prepulse inhibition of acoustic startle in schizophrenia. Biol Psychiatry. 2000;47:662-669.

60 Kumari V, Sharma T. Effects of typical and atypical antipsychotics on prepulse inhibition in schizophrenia: a critical evaluation of current evidence and directions for future research. Psychopharmacology. 2002;162:97-101.

61 Varty GB, Higgins GA. Examination of drug-induced and isolation-induced disruptions of prepulse inhibition as models to screen antipsychotic drugs. Psychopharmacology. 1995;122: $15-26$.

62 Varty GB, Higgins GA. Reversal of dizocilpine-induced disruption of prepulse inhibition of an acoustic startle response by the 5- $\mathrm{HT}_{2}$ receptor antagonist ketanserin. Eur J Pharmacol. 1995;287:201-205.

63 Swerdlow NR, Geyer MA, Braff DL. Neural circuit regulation of prepulse inhibition of startle in the rat: current knowledge and future challenges. Psychopharmacology. 2001;156:194-215.

64 Davis KL, Kahn RS, Grant K, Davidson M. Dopamine in schizophrenia: a review and reconceptualization. Am J Psychiatry. 1991;148:1474-1486.

65 Koch M, Bubser M. Deficient sensorimotor gating after 6hydroxydopamine lesion of the rat medial prefrontal cortex is reversed by haloperidol. Eur J Neurosci. 1994;6:1837-1845.

66 Ellenbroek BA, Budde S, Cools AR. Prepulse inhibition and latent inhibition: the role of dopamine in the medial prefrontal cortex. Neuroscience. 1996;75:535-542.

67 Hertel P, Nomikos GG, Iurlo M, Svensson TH. Risperidone: regional effects in vivo on release and metabolism of dopamine and serotonin in the rat brain. Psychopharmacology. 1996;124: 74-86.

68 Kuroki T, Meltzer HY, Ichikawa J. Effects of antipsychotic drugs on extracellular dopamine levels in rat medial prefrontal cortex and nucleus accumbens. J Pharmacol Exp Ther. 1999;288:774781.

69 Ichikawa J, Ishii H, Bonaccorso S, Fowler WL, O’Laughlin IA, Meltzer HY. 5- $\mathrm{HT}_{2 \mathrm{~A}}$ and $\mathrm{D}_{2}$ receptor blockade increases cortical DA release via $5-\mathrm{HT}_{1 \mathrm{~A}}$ receptor activation: a possible mechanism of atypical antipsychotic-induced cortical dopamine release. J Neurochem. 2001;76:1521-1531. 